\title{
Microscopic Characterizations of Green Chilli Powder
}

\author{
Mohammed Alsebaeai ${ }^{1,2 *}$, Anil Kumar Chauhan ${ }^{1}$, Arvind ${ }^{1}$, Poonam Yadav ${ }^{1}$, \\ Muneer AL-Sayadi ${ }^{2}$, Sam Al-Dalali ${ }^{2}$ and Hamid Al Eryani ${ }^{2}$
}

\author{
${ }^{1}$ Centre of Food Science and Technology, Institute of Agricultural Sciences, Banaras Hindu \\ University, Varanasi-221005, India \\ ${ }^{2}$ Department of Food Science and Technology, Faculty of Agriculture and Veterinary \\ Medicine, University of IBB, Yemen \\ *Corresponding author
}

\section{A B S T R A C T}

\section{Keywords}

Green chilli, Drying chilli, quality, SEM, XRD

\section{Article Info}

Accepted:

15 July 2018

Available Online:

10 August 2018
Green chilli was dried by different drying methods viz., lyophilize drying, Tray drying and Sun drying. Physio-chemical parameters, Scanning Electron Microscopy and X-Ray Diffraction in green chilli powder were investigated. Best results were observed by using lyophilize drying method in terms of Vitamin $\mathrm{C}$ and other qualities attribute in comparison to other drying methods. The characterization of green chilli powders was evaluated by Scanning Electron Microscopy and X- Ray Diffraction. The shape of green chilli powders particle was observed spherical and an amorphous form by using Scanning Electron Microscopy. The results obtained by X- Ray Diffraction indicated that there is no difference in the backbone structures of the green chilli powders.

\section{Introduction}

Green chilli is one of the most important spices in the world. It can be consumed as fresh or processed. It is seasonable crop that can be cheaper in season and expensive in off season. It is more important for processing green chilli to powder that can be available in off season in reasonable price to consumer. Alsebaeai, $\left(2017_{\mathrm{a}}\right.$ ) has been developed method for production of green chilli powder; Different drying method was used for production of green chilli powder. The result found that Lyophilize method the best for producing green chilli powder. The effect of the drying methods on the quality and bioactive compounds of green chilli powder was studied by (Alsebaeai et al., 2016; Alsebaeai et al., 2017b). Alsebaeai et al., (2017c) studied the effect of storability on the shelf life of green chilli powder using different packaging materials. It was found that green chilli packed on flexible aluminum foil at $5 \mathrm{C}^{\circ}$ can be extended Storability more than Six months without preservation.

Microscopy analysis is being progressively used in recent years to study the effect of material and conditions of processing on food structure (Wilson, 1991). Electron microscopy (EM) has been broadly utilized for the analysis of the microstructure of ingredients, 
food products and biological samples. In this method, electron waves are used to observe the specimen not light and there is different preparation is requiring for biological samples. The methods for preparation of biological samples are more complicated in comparison to other samples. Different electron microscopy methods including Transmission Electron Microscopy (TEM), Scanning Electron Microscopy (SEM), CryoSEM, CryoTEM, and Environmental Scanning Electron Microscopy (ESEM) have been applied for the determined related to process of food (Fazaeli et al., 2012).

Ajayan et al., (1997) found that the scanning electron microscope (SEM) is the most versatile and widely used electron beam instrument all over the Globe. It owes because of its popularity such as easily interpreted and generates the nature of the micrographs, the use of the SEM for characterization of food materials. Yang et al., (1997) also reported that the basic use of the SEM has always been in the imaging of surface topography. Fultz and Howe (2012) reported that size and composition are the most fundamental attributes like- crystals. X-Ray diffraction methods (XRD) is very useful characterization tool and a quick analytical method which is used to identify and characteristic of phase like crystalline material and also provides data to unit cell measurements came about as finely ground, homogenized and average bulk composition. All diffraction analyses are based on creating of X-Rays in X-ray tube (Dorset, 1998; Sharma et al., 2012). The aim of this study was to studied the microstructure of green chilli powders produced by different drying methods

\section{Materials and Methods}

The samples of green chilli were procured from local market of Varanasi, UP, India. The experiments were conducted at Centre of Food
Science and Technology, Institute of Agricultural Sciences; Department of Pharmacy and IIT central Facility, Indian Institute of technology; Department of Botany, Faculty of Sciences; at Banaras Hindu University, Varanasi (UP), India.

\section{Processing of green chilli powder}

The producing of green chilli powders were done by using three drying methods viz., Lyophilize, Tray and Sun drying. The dried green chilli was grinding by using electric machine.

After that the powder was passing through mash than packed in polyethylene and storage at $5^{\circ}$ for future study.

\section{Chemical analysis of fresh green chilli and powders}

Moisture content, crud fat, crud protein, ash, crud fiber and vitamin C contents were analyzed by the method of (Intl AOAC, 1995). Reducing sugar was estimated by Lane and Eynon's method reported by Ranganna (1986).

\section{Microstructure analysis of green chilli powders}

\section{Scanning Electron Microscopy (SEM)}

All samples of green chill powders were examined by Scanning Electron Microscopy (SEM) Hitachi S-570 camera (Hitachi Ltd., Tokyo, Japan) operated at an accelerating voltage of $20 \mathrm{kV}$ (Caparino et al., 2012).

A small quantity $(180-250 \mu \mathrm{g})$ of all green chilli sample of powders were mounted on aluminum stubs and coated with a fine layer of gold $(15 \mathrm{~nm})$ using a Sputter gold coater. After that the lower mentioned pictures were obtained. 


\section{X-Ray Diffraction}

X-Ray Diffraction (XRD) characteristics of green chilli powders were obtained using a Siemens D-500 diffractometer (Bruker, Karlsruhe, Germany) of different drying processes. The powder samples $(180-250 \mu \mathrm{g})$ were placed and slightly pressed in an aluminum holder using a glass slide. The diffractometers were working at a wavelength of $0.15 \mathrm{~nm}$ and the input energy was adjusted at $35 \mathrm{kV}$ and $30 \mathrm{~mA}$. Diffract grams were taken at $(2 \theta)$ with a step angle of $0.02^{\circ}$ and scan rate of $1 \mathrm{~s}$ per step. The XRD patterns of all green chilli powder samples were plotted for comparison (Caparino et al., 2012).

\section{Statistical analysis}

Means of the triplicate values and standard deviations from the obtained data were calculated and statistically analyzed using SAS version 9.1. Meanwhile, Duncan's multiple range tests were applied to determine the differences in the different among the samples.

\section{Results and Discussion}

\section{Composition of fresh green chilli}

The fresh green chilli was analyzed for moisture, protein, fat, ash, fiber and vitamin C and the results are presented in Table 1 . The fresh green chilli contained $86.53 \%$ moisture, $5.30 \%$ protein, $1.39 \%$ fat, $0.95 \%$ ash, 109.24 $\mathrm{mg} / 100 \mathrm{~g}$ vitamin $\mathrm{C}, 2.90 \%$ fiber and 5.69 $\mathrm{mg} / \mathrm{g}$ reducing sugar.

The results of proximate chemical composition of fresh green chilli is similar to results reported by Srivastava et al., (2005). Who found $85.5 \%$ moisture, $5.4 \%$ protein, 1.1 $\%$ fat, $1.2 \%$ mineral, $110 \mathrm{mg}$ per $\%$ of vitamin C. Also Take and Bhotmange (2012) found that the moisture was $89-92 \%$,Total ash
0.55-0.65\%, Ascorbic acid 23.25-29.33 $\mathrm{mg} / 100 \mathrm{~g}$. Ozgur and Ozcan (2011) reported that the moisture of green chilli was $94.50 \%$, Total ash $0.31 \%$ Ascorbic acid 64.07 and Total phenols 96.04 (mg GAE g DW-1). Singh et al., (2015) has reported that green chilli contained 86.3-87.5\% moisture, 1.4$2.3 \%$ protein, $0.9-1.5 \%$ fat, $1.02-1.2 \%$ mineral and $98-104 \mathrm{mg}$ per $\%$ of vitamin C. Take $e t$ al., (2012) also reported that the composition of green chilli viz. Moisture content (98-92\%), Ash (0.55-0.65\%), Reducing sugar (2.8-3.6 g $/ 100 \mathrm{~g})$, Ascorbic acid $(23.25-29.33 \mathrm{mg} / 100 \mathrm{~g})$ were agreed with this research.

\section{Effect of drying methods in the Quality of green chilli powder}

The quality of green chilli powders was depended on the methods of drying processing viz., Lyophilize, Tray and Sun. The chemical parameter like- moisture, ash, protein, fat and vitamin $\mathrm{C}$ were analyzed and the results are presented in Table 2.

The moisture content of samples was found 7.44-9.26\%. Krishnamurthy and Natarajan, (1973) reported that moisture content of green chilli powders is $8-10 \%$. Also results were agreed with Singh et al., (2015).

Rani and Usha Rani, (1996) also resulted that ash content ranging from 4.53 to $7.39 \%$ in green chilli powder. Similarly, Luhadiya and Kulkarni, (1978) found that the ash content was $5.60 \%$. The result was more than (3.9$4.8 \%$ ) that reported by Singh et al., (2015).

The protein content in green chilli powders were ranging between $14.85-16.27 \%$. The results are presented in Table 2 . The results were agreed with Srivastava and Kumar, (1994) who reported that the protein content was $15.4 \%$. There are significant $(\mathrm{P}<0.05)$ differences between all drying methods due to drying method. 
Table.1 Chemical composition of fresh green chilli

\begin{tabular}{|c|c|}
\hline Compounds & Raw green chilli \\
\hline Moisture (\%) & $86.53 \pm 0.96$ \\
\hline Ash (\%) & $0.95 \pm 0.12$ \\
\hline Crud Protein (\%) & $5.30 \pm 0.17$ \\
\hline Reducing sugar (mg/g) & $5.69 \pm 0.32$ \\
\hline Crud fat (\%) & $1.39 \pm 0.02$ \\
\hline Ascorbic acid (mg/100g) & $109.24 \pm 0.32$ \\
\hline Crud Fiber (\%) & $2.90 \pm 0.17$ \\
\hline
\end{tabular}

* Each value is Mean \pm Standard Deviations $(\mathrm{n}=3)$.

Table.2 Chemical composition of green chilli powders

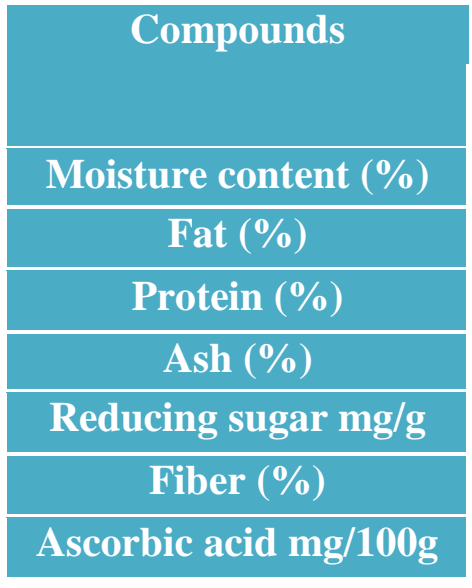

\begin{tabular}{|c|c|c|}
\hline \multicolumn{3}{|c|}{ Samples } \\
\hline SGCP & TGCP & LGCP \\
\hline $8.37 \pm 0.50^{\mathrm{a}}$ & $7.44 \pm 0.15^{\mathrm{b}}$ & $9.26 \pm 0.12^{\mathrm{c}}$ \\
\hline $5.09 \pm 0.20^{\mathrm{a}}$ & $5.28 \pm 0.60^{\mathrm{a}}$ & $5.50 \pm 0.51^{\mathrm{a}}$ \\
\hline $14.85 \pm 0.18^{\mathrm{a}}$ & $14.95 \pm 0.09^{\mathrm{a}}$ & $16.27 \pm 0.37^{\mathrm{c}}$ \\
\hline $9.18 \pm 0.23^{\mathrm{a}}$ & $7.57 \pm 0.32^{\mathrm{b}}$ & $6.99 \pm 0.17^{\mathrm{c}}$ \\
\hline $95.16 \pm 0.57^{\mathrm{a}}$ & $80.55 \pm 0.33^{\mathrm{b}}$ & $89.05 \pm 0.20^{\mathrm{c}}$ \\
\hline $24.44 \pm 0.17^{\mathrm{a}}$ & $24.52 \pm 0.19^{\mathrm{a}}$ & $24.64 \pm 0.16^{\mathrm{a}}$ \\
\hline $90.70 \pm 0.30^{\mathrm{a}}$ & $130.50 \pm 0.10^{\mathrm{b}}$ & $165.20 \pm 0.20^{\mathrm{c}}$ \\
\hline
\end{tabular}

* Each value is Mean \pm Standard Deviations $(\mathrm{n}=3)$.

Different superscripts in row are significantly different $(P<0.05)$.

LGCP: Lyophilize Green Chilli Powder

TGCP: Tray Green Chilli Powder

SGCP: Sun Green Chilli Powder

Table.3 XRD parameter of green chilli powders

\begin{tabular}{|l|c|c|c|c|c|c|}
\hline No. & 2-theta (deg) & D (ang.) & $\begin{array}{c}\text { Height } \\
(\text { counts })\end{array}$ & $\begin{array}{c}\text { FWHM } \\
(\mathbf{d e g})\end{array}$ & $\begin{array}{c}\text { Size } \\
(\mathbf{a n g} .)\end{array}$ & $\begin{array}{c}\text { Rel. int. I } \\
(\mathbf{a . u .})\end{array}$ \\
\hline LGCP & $21.50 \mathrm{a}$ & $4.129 \mathrm{a}$ & $2321 \mathrm{a}$ & 6.35 & 13.30 & 100.00 \\
\hline TGCP & $21.20 \mathrm{a}$ & $4.187 \mathrm{a}$ & $2081 \mathrm{~b}$ & 6.41 & 13.17 & 100.00 \\
\hline SGCP & $21.75 \mathrm{a}$ & $4.083 \mathrm{a}$ & $2819 \mathrm{c}$ & 6.71 & 12.59 & 100.00 \\
\hline
\end{tabular}


Fig.1 Scanning electron micrographs obtained from lyophilize green chilli powder

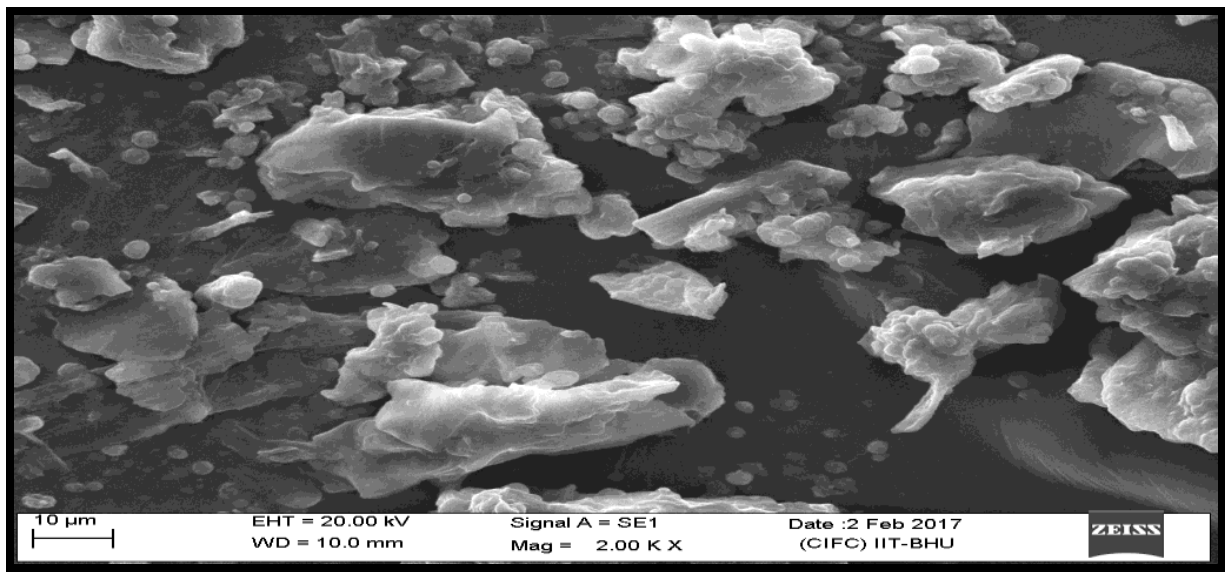

Fig.2 Scanning electron micrographs obtained from tray green chilli powder

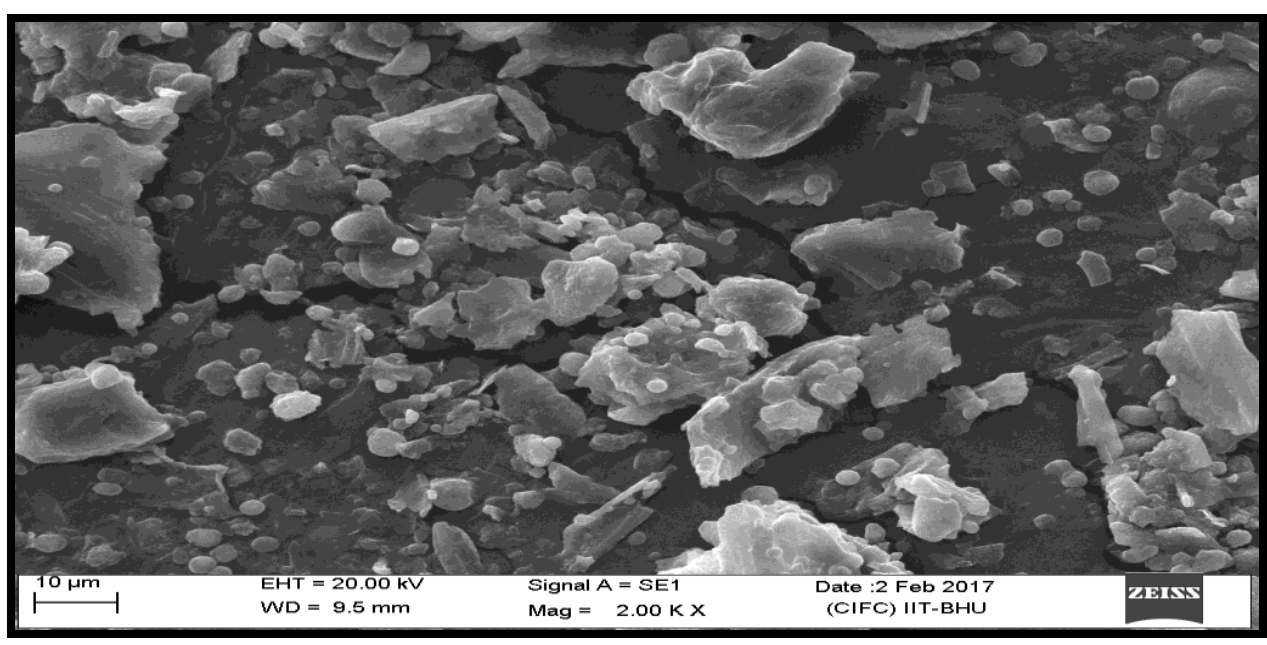

Fig.3 Scanning electron micrographs obtained from sun green chilli powder

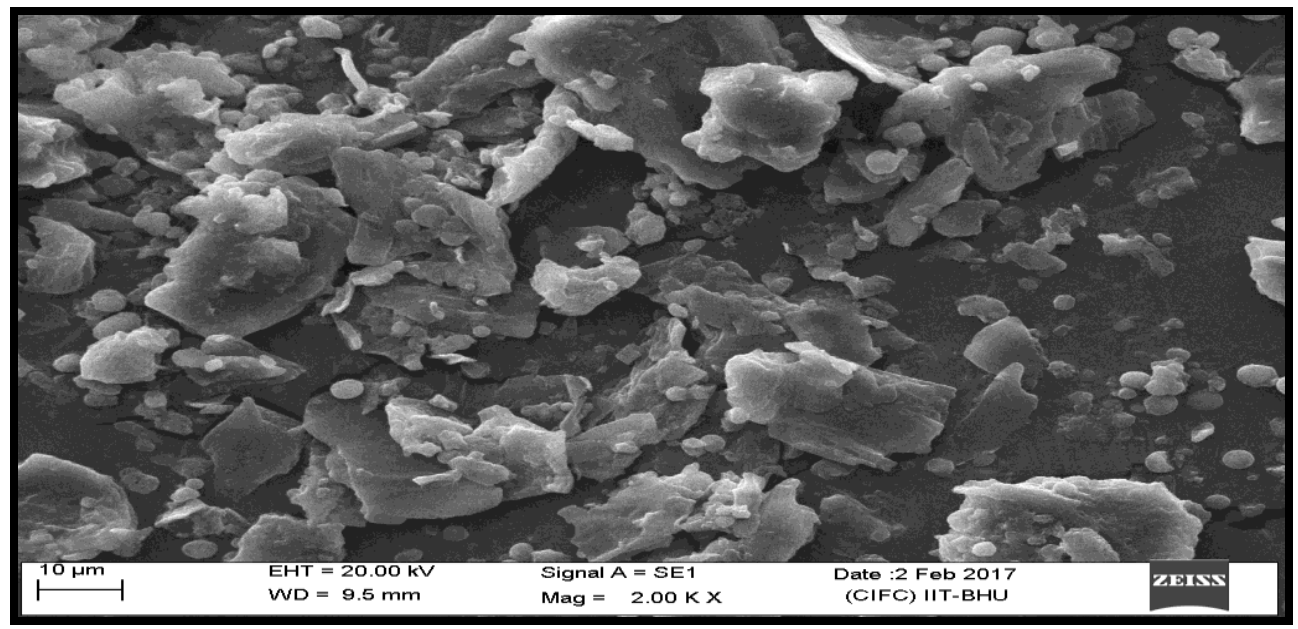


Fig.4 XRD of lyophilize green chilli powder

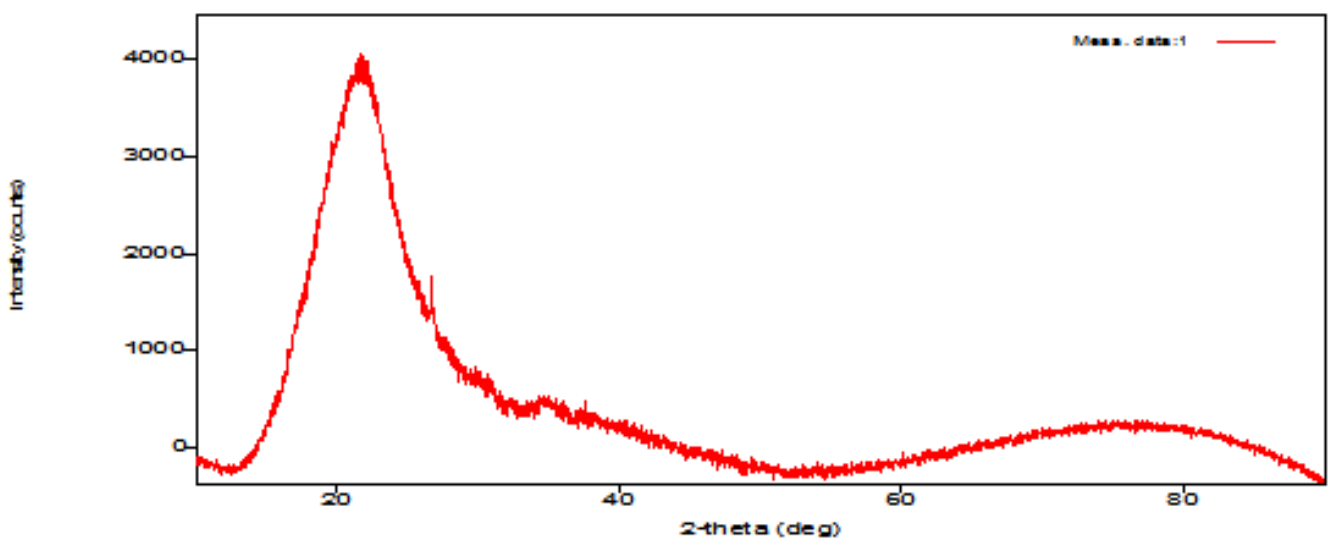

Fig.5 XRD of Tray green chilli powder

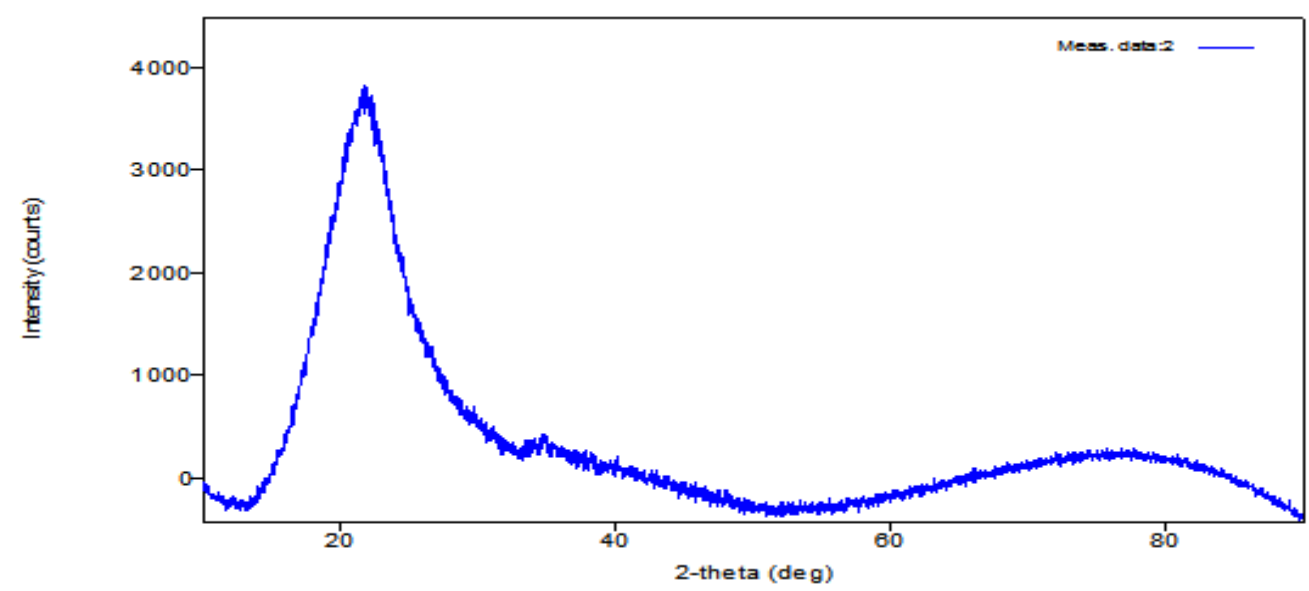

Fig.6 XRD of Sun green chilli powder

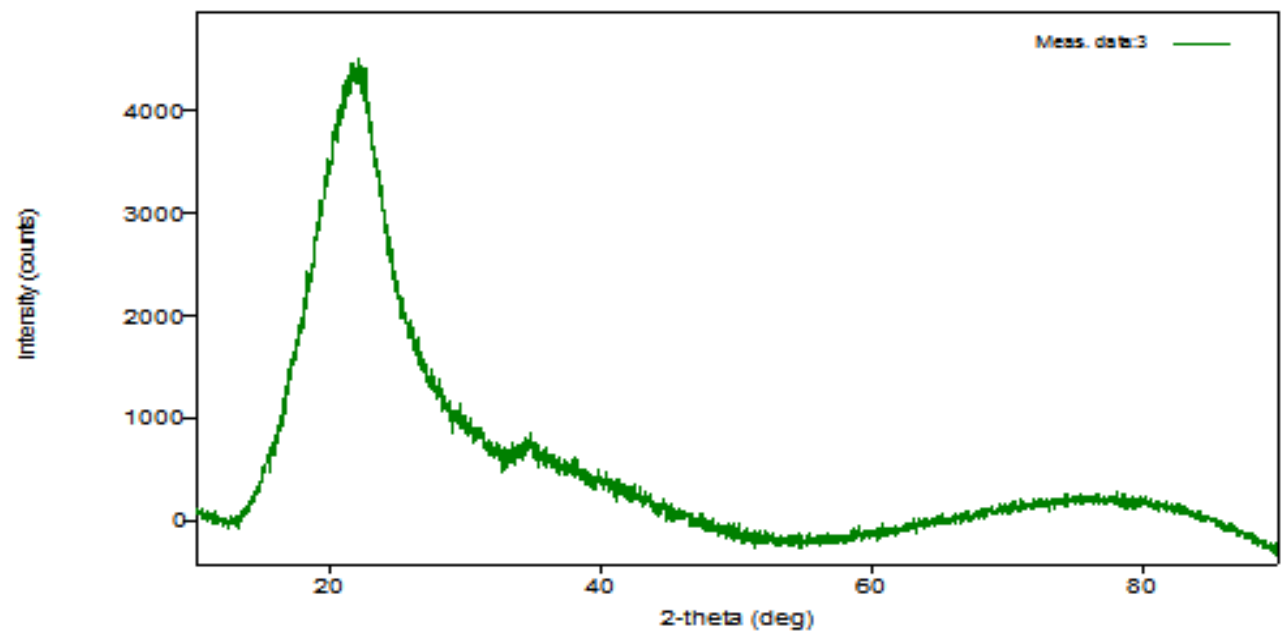


Crud fat content of green chilli powders are presented in Table 2. The result ranged between 5.09-5.50\%. The results were more than $(6.2 \%$ dry chilli per $100 \mathrm{~g})$ reported by Srivastava and Kumar, (1994). Also results were agreed with (3.7-4.3\%) (Singh et al., 2015). The result of reducing sugar content of green chilli powder was presented in Table 2 . The results were ranged between 80.55-95.16 $\mathrm{mg} / 100 \mathrm{~g}$, and the results were similar to (41$180 \mathrm{mg} / 100 \mathrm{~g})$ reported by Take et al., (2012).

The Ascorbic acid content in green chilli powders were ranged between 90.70$165.20 \%$. The results are presented in Table 2 . The results were agreed with the finding $184 \mathrm{mg}$ per $100 \mathrm{~g}$ dry chilli Wu Leung et al., (1972). Simultaneously, results were also similar to $85.7-124.3 \mathrm{mg} / 100 \mathrm{~g}$ reported by Singh et al., (2015).

Moisture content was higher in Lyophilize Green Chilli Powder that due to condition of Lyophilize drying in comparison to tray drying (Time and temperature). While there was no significant differences between drying method on fat contain. increasing ash contain in sun green chilli powder sample due to the condition of sun drying, the sample was lift in outside so that maybe allowed some dust to mixed with samples. Decrease Ascorbic acid in sun green chilli powder maybe due to different chemical reaction motivate by air and light during sun drying. Kaya et al., (2010) found that increasing temperature of drying causes more loss in vitamin $\mathrm{C}$ in the dried fruits while degradation of vitamin $C$ is reduced with increasing relative humidity of drying air.

\section{Morphological characterization of green chilli powders by SEM}

Scanning Electron Microscopy (SEM) is very useful characterization tool to provide images about the morphology, size, shape, and organization of the surface topography of samples (Egerton, 2005; Otunola et al., 2017).

The analysis of the surface of powder particles from green chilli obtained by different drying methods were carried out in a three-dimensional character through electronic microscopy. The photomicrographies are shown in figure 1, 2 and 3. The typical pulverized particles were showed that the dried green chilli was crushed into very small particle the edge of the particle was rounded and it was destroyed in the amorphous region. It was observed that the morphology of lyophilize, tray and sun green chilli powders was almost similar. It is verified with the help of Figure 1, 2 and 3 that the green chilli powders samples presented several forms of particles.

Tremlová (2001) reported that SEM can be used for determination of verify the adulteration in food sample, also Zhu and Zhao, (2014) studied apply the microscopic powder identification technique to determining the adulterated seasoning powders from several plant origins, such as chili, cumin, pepper and mustard. It has ability to detect the micro-morphology of the adulterating substances directly that will help for detected foreigner material in any product. Also it will give idea about purity of the material.

\section{XRD characterization of green chilli powders}

Crystallization is a great importance for the stability of powder and can be determined by $\mathrm{X}$-ray diffraction analysis. The presence of spread and large peaks in X-Ray Diffraction containing amorphous material is due to the fact that, in the amorphous state, the molecules are disorderly displayed producing disperse bands whereas crystalline materials 
yield sharp and defined peaks since they are presented in a highly ordered state (Athmaselvi et al., 2014; Cano-Chauca et al., 2005).

The structural properties of the three green chilli powders were studied by XRD (Fig. 4, $5,6)$. The parameters of the main diffraction peaks from green chilli powders are shown in Table 3. The typical diffraction patterns of green chilli powders had high peaks at $2 \theta$ value ranged between $21.20-21.75^{\circ}$. It was observed that the curve of lyophilize, Tray and sun green chilli powders was similar.

Green chilli powders obtained through sun drying showed a high crystalline peak at a $2 \theta$ value of about $21.75^{\circ}$ and a small peak at a $2 \theta$ value were found on sample obtained from tray drying $\left(21.20^{\circ}\right)$. The angle locations of three sample of green chilli powder were not statistically significantly different $(\mathrm{P}<0.05)$.

The average distance between particles (dhkl) of green chilli powders obtained by different drying methods at $2 \theta$ was not significantly different $(\mathrm{P}<0.05)$ (Table 3). Lyophilize green chilli powders sample was 4.129 while tray green chilli powders found 4.187 and the lowest result was found in sun green chilli powder sample. The results indicated that there is no difference in the backbone structures of the green chilli powders.

The shape of curve will decided the type of material. According to the curve the green chilli powders in all sample had single peak that means, green chilli powder is amphorae materials. There was not significantly different $(P<0.05)$ between all green chillies powders. Zhao et al., (Zhao et al., 2015) was studied the microstructure of soy protein and the results showed that the a crystalline peak at a $2 \theta$ value was ranged between 19.60 $19.80^{\circ}$. The result was found lower than our finding.
Based on the results obtained, it can be concluded that the green chilli powder produced by lyophilize methods has better qualities attributes in term of vitamin $\mathrm{c}$ and color. By using Scanning Electron Microscopy it was observed that the shape of green chilli powders particle was spherical and in amorphous form. The results obtained by X-Ray Diffraction indicated that there is no difference in the backbone structures of the green chilli powders.

\section{Acknowledgement}

Instruments and Chemical provided by Centre of Food Science and Technology, Department of Pharmacy (IIT) and IIT central Facility, Banaras Hindu University are dully acknowledged.

\section{References}

Ajayan, P. M., Redlich, P., and Ru“ hle, M. (1997). Structure of carbon nanotube- based nanocomposites. Journal of Microscopy, 185(2), 275282.

Alsebaeai, M., Chauhan, A. K., Arvind, and Hemalatha, S. (2017c). Effect of Storagibility on the Shelf Life of Green Chilli Powder Using Different Packaging Materials. International Journal of Innovative Research in Science, Engineering Engineering and Technology, 6(9), 18595-18602. https:// doi.org/10.15680/IJIRSET.2017.060915 5

Alsebaeai, M. (2017 $)$. Development and production technology for green chilli powder. Centre of Food Science and Technology Institute of Agricultural Sciences Banaras Hindu University Varanasi (Ph.D Thesis).

Alsebaeai, M., Chauhan, A., Arvind, Singh, R. P., Yadav, P., Fatma, S., and Maurya, K. K. (2016). Effect of 
Thermal Treatment on The Bioactive Compounds in Green Chilli Powder. International Journal of Agricultural Science and Research, 6(6), 201627.

Alsebaeai, M., Chauhan, A. K., Arvind, Hemalatha, S., and Yadav, P. (2017b). Effect of the drying methods on the quality and characterization of green chilli powder. International Journal of Food Science and Nutrition, 2(6), 1823.

Athmaselvi, K. A., Kumar, C., Balasubramanian, M., and Roy, I. (2014). Thermal, structural, and physical properties of freeze dried tropical fruit powder. Journal of Food Processing, 2014.

Cano-Chauca, M., Stringheta, P. C., Ramos, A. M., and Cal-Vidal, J. (2005). Effect of the carriers on the microstructure of mango powder obtained by spray drying and its functional characterization. Innovative Food Science and Emerging Technologies, 6(4), 420-428.

Caparino, O. A., Tang, J., Nindo, C. I., Sablani, S. S., Powers, J. R., and Fellman, J. K. (2012). Effect of drying methods on the physical properties and microstructures of mango (Philippine 'Carabao'var.) powder. Journal of Food Engineering, 111(1), 135-148.

Dorset, D. L. (1998). X-ray diffraction: a practical approach. Microscopy and Microanalysis, 4(5), 513-515.

Egerton, R. F. (2005). Physical principles of electron microscopy: an introduction to TEM. SEM, and AEM, 34-35.

Fazaeli, M., Tahmasebi, M., and Djomeh, E. Z. (2012). Characterization of food texture: application of Microscopic technology. Current Microscopy Contributions to Advances in Science and Technology, 1, 855-871.

Fultz, B., and Howe, J. M. (2012). Transmission electron microscopy and diffractometry of materials. Springer
Science and Business Media.

Intl, A. (1995). Official methods of analysis of AOAC International. Arlington, Va.: AOAC Intl. Pv (Loose-Leaf).

Kaya, A., Aydın, O., and Kolaylı, S. (2010). Effect of different drying conditions on the vitamin $\mathrm{C}$ (ascorbic acid) content of Hayward kiwifruits (Actinidia deliciosa Planch). Food and Bioproducts Processing, 88(2), 165-173.

Krishnamurthy, M. N., and Natarajan, C. P. (1973). Colour and its changes in chillies. Indian Food Packer, 27(1), 3944.

Luhadiya, A. P., and Kulkarni, P. R. (1978). Dehydration of green chillies (Capsicum frutescens). Journal of Food Science and Technology.

Otunola, G. A., Afolayan, A. J., Ajayi, E. O., and Odeyemi, S. W. (2017). Characterization, antibacterial and antioxidant properties of silver nanoparticles synthesized from aqueous extracts of Allium sativum, Zingiber officinale, and Capsicum frutescens. Pharmacognosy Magazine, 13(Suppl 2), S201.

Ozgur, M., and Ozcan, T. (2011). Functional compounds and antioxidant properties of dried green and red peppers. African Journal of Agricultural Research, 6(25), 5638-5644. https://doi.org/10.5897/AJAR11.709

Ranganna, S. (1986). Handbook of analysis and quality control for fruit and vegetable products. Tata McGraw-Hill Education.

Rani, P. U., and Usha Rani, P. (1996). Studies on fruit weight and its related characters in chilli (Capsicum annum L.). Intl. J. Trop. Agric, 14, 123-130.

Sharma, R., Bisen, D. P., Shukla, U., and Sharma, B. G. (2012). X-ray diffraction: a powerful method of characterizing nanomaterials. Recent Research in Science and Technology, 4(8). 
Singh, A., Chauhan, A. K., Singh, R. P., Yadav, P., and ALsebaeai, M. (2015). Development of Production Technology To Manufacture of Green Chili Powder. Proceeding - Kuala Lumpur International Agriculture, Forestry and Plantation, 1-13.

Srivastava, R. P., and Kumar, S. (1994). Fruit and vegetable preservation: Principles and practices. CBS Publishers and Distributors Pvt. Limited.

Srivastava, R. P., Srivastava, R. P., and Kumar, S. (2005). Fruit and vegetable preservation: principles and practices. International Book Distributing Company.

Take, A., SL, J., and Bhotmange MG. (2012). Effect of Pretreatments on Quality Attributes of Dried Green Chilli Powder. ISCA Journl of Enginering Sciences, 1(1), 71-74

Take, Jadhav, and Bhotmange. (2012). Effect of pretreatments on quality attributes of dried green chilli powder. ISCA J Eng Sci, 1(1), 71-74.

TREMlovÁ, B. (2001). Evidence of spice black pepper adulteration. Czech Journal of Food Sciences, 19(6), 235-
238.

Wilson, A. J. (1991). Microscopical methods for examining frozen foods. In Food Freezing (pp. 97-112). Springer.

Wu Leung, W. T., Rauanheimo Butrum, R., Huang Chang, F., Narayana Rao, M., and Polacchi, W. (1972). Food composition table for use in East Asia. Food and Agriculture Org.

Yang, W., Weatherly, G. C., McComb, D. W., and Lloyd, D. J. (1997). The structure of $\mathrm{SiC}$ - reinforced $\mathrm{Mg}$ casting alloys. Journal of Microscopy, 185(2), 292-302.

Zhao, X., Zhu, H., Zhang, B., Chen, J., Ao, Q., and Wang, X. (2015). XRD, SEM, and XPS analysis of soybean protein powders obtained through extraction involving reverse micelles. Journal of the American Oil Chemists' Society, 92(7), 975-983.

Zhu, H., and Zhao, M. (2014). Study on the Microscopic Identification of the Adulterated Plant Origin Powdered Seasonings. Discourse Journal of Agriculture and Food Sciences, 2(9), 264-269.

\section{How to cite this article:}

Mohammed Alsebaeai, Anil Kumar Chauhan, Arvind, Poonam Yadav, Muneer AL-Sayadi, Sam Al-Dalali and Hamid Al Eryani. 2018. Microscopic Characterizations of Green Chilli Powder. Int.J.Curr.Microbiol.App.Sci. 7(08): 2488-2497. doi: https://doi.org/10.20546/ijcmas.2018.708.252 